\title{
Gender, Stock Market Participation and Financial Literacy ${ }^{*}$
}

\author{
Johan Almenberg a and Anna Dreber ${ }^{\mathrm{b}}$ \\ SSE/EFI Working Paper Series in Economics and Finance \\ No 737 \\ First version: 2011
}

This version: June 2012

\begin{abstract}
Women typically participate less than men in the stock market, while also scoring lower on financial literacy. We explore the link between the gender gap in stock market participation and financial literacy. Using survey data on a random sample of 1,300 individuals that is representative of the Swedish population, we show that controlling for basic financial literacy, essentially a measure of numeracy that does not require knowledge about the stock market, may explain a large part of the gender gap in stock market participation. We also find that women report being less risk taking than men. This gender gap in risk attitudes remains significant also when controlling for financial literacy.
\end{abstract}

Keywords: stock market participation, gender, financial literacy, numeracy, risk attitudes

JEL Classification: D14, G11

\footnotetext{
* We thank the Swedish Financial Supervisory Authority (Finansinspektionen) for making this study possible. We are grateful for comments from Emma von Essen, Magnus Johannesson, Markku Kaustia, Astri Muren, Eva Ranehill and Marta Serra-Garcia, and financial support for A.D. from the Swedish Institute of Banking Research (Bankforskningsinsitutet) and the Jan Wallander and Tom Hedelius Foundation (Handelsbankens forskningsstiftelser).

a Ministry of Finance, Drottninggatan 21, 10333 Stockholm, Sweden. Email: johan.almenberg@gmail.com. Corresponding author. The views in this paper are those of the authors in their capacity as researchers and do not represent the views of the Ministry of Finance.

b Department of Economics, Stockholm School of Economics, P.O. Box 6501, 11383 Stockholm, Sweden. Email: anna.dreber@hhs.se.
} 


\section{Introduction}

We examine whether some of the commonly observed gender gap in stock market participation can be explained by differences in financial literacy. We distinguish between basic financial literacy, essentially a measure of numeracy that does not require knowledge about the stock market, and advanced financial literacy directly involving familiarity with financial products and concepts.

Stock market participation is an important economic outcome. There can be a substantial welfare loss from not participating in the stock market, as exposure to equities, and hence to the equity premium, may be an important determinant of the long-run return to individual savings (Cocco et al. 2005). Yet, there is substantial variation in stock market participation between individuals, with many households not holding any stocks at all (e.g. Campbell 2006, Guiso et al. 2008).

A number of factors have been proposed for the substantial non-participation even among households that can afford to save, including cognitive ability (e.g., Benjamin et al. 2006, Kezdi and Willis 2006, Grinblatt et al. 2011), fixed participation costs (e.g., Haliassos and Bertaut 1995, Vissing-Jørgensen 2003), lack of stock market awareness or social connections (e.g., Hong et al. 2004, Guiso and Jappelli 2005, van Rooij et al. 2011), lack of trust (Guiso et al. 2008), and risk aversion (e.g. Halko et al. forthcoming). ${ }^{1}$

Financial literacy in the form of knowledge about the stock market has also been related to stock market participation. In a study of a representative sample of the Dutch population, van Rooij et al. (2011) find that many families shy away from the stock market because they have little knowledge of stocks and the stock market. ${ }^{2}$ It has also been shown that more basic measures of financial literacy, essentially measures of numeracy, can predict stock market participation. Christelis et al. (2010) find that this is the case when exploring numeracy (as well as verbal fluency and recall skills) among a sample of individuals aged 50+ in 11 European countries, with detailed data on wealth and portfolio composition.

\footnotetext{
${ }^{1}$ Several of these explanations are related to information costs. Cognitive ability could also be related to variation in preferences, in particular since e.g. risk aversion has been found to correlate negatively with cognitive ability (Frederick 2005, Benjamin et al. 2006, Dohmen et al. 2010), however Christelis et al. (2010) argue that the link between cognitive ability and stockholding is more likely to be about information constraints since they don't find a correlation between bond holding (that requires less information than stocks) and cognitive ability.

${ }^{2}$ Van Rooij et al. (2011) explore two types of financial literacy. As we discuss below, we base our advanced measure on the one used in their paper (introduced by Lusardi and Mitchell 2006). Their basic measure is however more advanced than the one we use here, since the basic measure used in this paper is essentially a numeracy measure.
} 
On average, women participate less than men in the stock market (van Rooij et al. 2011). This gender gap may be reduced by controlling for variables such as education, wealth and risk preferences, as shown in e.g. Haliassos and Bertaut (1995) and Halko et al. (forthcoming). Meanwhile, women are typically less financially literate than men (see Lusardi 2008 for a discussion).

In this paper we relate the gender gap in stock market participation to basic financial literacy, essentially a measure of numeracy that does not require specific knowledge about the stock market. Previous studies have focused on advanced financial literacy. We find that basic financial literacy can explain a large part of the gender gap in stock market participation. Our results are robust for the inclusion of a measure of advanced financial literacy, which picks up knowledge about the stock market. This variable is also related to stock market participation, but can on a priori grounds be considered more endogenous: participation in the stock market is likely to increase an individual's knowledge about finance. By contrast, it is not evident that stock market participation improves an individual's numeracy. This implies that the causation can be expected to go from numeracy to stock market participation and not vice versa.

The data also allows us to shed some light on a related issue: whether basic and advanced financial literacy can explain part of the gender gap in risk attitudes. The survey includes a risk measure similar to that used in e.g. Dohmen et al. (2011), and which has been shown to be a good predictor of various types of risk taking. ${ }^{3}$

We find that women are significantly less risk taking than men according to this measure. Basic financial literacy is not correlated with risk preferences whereas advanced financial literacy is. However, the gender gap remains significant even when we control for financial literacy. This result matters because attitude toward risk taking is in itself an important determinant of stock market participation and other important decisions in a number of domains. Moreover, this contributes to the understanding of the often observed gender gap in risk preferences (Croson and Gneezy 2009). The two papers that are most closely related to our examination of the link between financial sophistication or financial knowledge and the gender gap in risk attitudes are Dwyer et al. (2002) and Halko et al. (forthcoming). Dwyer et al. (2002) find that the gender gap in risk taking decreases significantly once controls for a variable related to advanced financial literacy is included, whereas Halko et al. (forthcoming) find that the gender gap in risk attitudes with the same type of measure as used here remains

\footnotetext{
${ }^{3}$ Dohmen et al. (2011) find that this risk question is the overall best explanatory variable in terms of predicting risk taking in a wide range of contexts.
} 
significant once they control for investment knowledge. A key difference is that we also explore basic financial literacy, which is less likely to be endogenous to participation on financial markets. Our findings suggest that the gender gap in risk attitudes according to the survey question cannot easily be explained by gender differences in financial literacy.

Our data is from the 2010 consumer survey conducted by the Swedish Financial Supervisory Authority (Finansinspektionen). The participants constitute a random sample of 1,300 adults in Sweden aged 18-79, approximately representative of the Swedish population.

The consumer survey contains standard measures of both basic and advanced financial literacy. These or closely related measures have been linked to household financial decision making in important ways. Less financially literate households borrow more (Agarwal et al. 2009, Lusardi and Tufano 2009), save less (Lusardi and Mitchell 2007), and are less likely to plan for retirement (Lusardi and Mitchell 2007, Almenberg and Säve-Söderbergh 2011).

We use a standard measure of stock market participation: direct stock market participation through ownership of stocks and/or indirect participation through ownership of shares in mutual funds. The same measure is used by for example Vestman (2010). The measure excludes stock market participation through pension plans, including mandatory retirement accounts.

From the consumer survey we also use a question on risk attitudes that asks about the individual's willingness to take risk in general, on a scale from 1 to 10 . A similar measure has been used previously by e.g. Dohmen et al. (2011).

In sum, our results suggest that gender differences in financial literacy can explain a significant part of the gender gap in stock market participation. Failing to include controls for financial literacy is thus likely to overstate the effect of gender on stock market participation. Our results also show that basic and advanced financial literacy have separate and distinct effects, thus leading support to viewing these as distinct albeit related competencies (see Hung et al. 2009 for a discussion).

In terms of policy conclusions, our findings suggest that one way to decrease the gender gap in stock market participation may be to increase numeracy skills, i.e. raise basic financial literacy, among women. Moreover, our findings suggest that the gender gap in risk attitudes according to the survey question cannot easily be explained by gender differences in financial literacy. 
The outline for our paper is the following. In section 2, we present the data. We present our results in section 3, and finish with a discussion in section 4 .

\section{Data}

\subsection{Data collection}

We use a simple random sample of the 1,300 adults in the Swedish population. The data is from a consumer survey commissioned by the Swedish Financial Supervisory Authority and executed by a private contractor in May-June 2010. The survey is described in detail in Almenberg and Widmark (2011).

An independent random sample that is representative of the Swedish population between the age of 18 and 79 was generated using the data from Statens personadressregister (SPAR). The SPAR database contains all individuals registered as being resident in Sweden at any given time, irrespective of their citizenship. Phone numbers for the individuals in the sample were collected from the PAR-database. The phone numbers in PAR are collected from all the major phone providers in Sweden, and include both fixed numbers and registered cell phone numbers. In order to minimize non-response, the individuals in the sample were called up to 8 times at different times of day and on different days until contact was made. The participation rate was 45 percent, which is a common figure in terms of survey participation in Sweden. There were no monetary incentives for participation.

The survey was targeted at individuals, rather than households, and participation was not conditional on being the main decision maker about the household's finances. The data is cross-sectional. The respondents had not received the questions before.

\subsection{Measuring basic and advanced financial literacy}

The survey questionnaire includes two sets of questions aimed at measuring financial literacy (see Appendix). The first set of questions measures basic financial literacy, essentially the ability to perform basic calculations, i.e. numeracy. This set of six questions has previously been used in the English Longitudinal Study of Ageing (ELSA; Steel et al. 2003, Banks and Oldfield 2007) and in the US Health and Retirement Survey (HRS) and examined in relation to financial decision making by, for example, Lusardi and Mitchell (2007) and McArdle, Smith and Willis (2009). Four out of six of these questions are also used in Christelis et al. (2010), who refer to these questions as an indicator of cognitive ability. The second set of questions measure advanced financial literacy, in particular familiarity with financial products 
and concepts. These questions are largely based on the financial literacy questions designed by Annamaria Lusardi and Olivia Mitchell for the HRS and the Rand American Life Panel (Lusardi and Mitchell 2006, 2007). See Almenberg and Widmark (2011) for a detailed analysis of these two measures and Lusardi (2012) for a general discussion of the relationship between numeracy and financial literacy.

\subsection{Measuring risk attitudes}

The survey questionnaire also includes a question on the individual's general willingness to take risks, expressed on a scale from 1 to 10 , where 1 is not risk taking at all and 10 is very risk taking. A similar question has been used in e.g. Dohmen et al. (2011), who show that is a good predictor of a number of risky behaviors, including holding stocks, being self-employed, smoking, migrating, and occupational choice. Moreover, Dohmen et al. (2010) show that risk taking according to this question is positively related to cognitive ability. We use this continuous measure as a proxy of risk attitudes. ${ }^{4}$

\section{Results}

\subsection{Descriptive statistics}

The sample is evenly divided between men and women, 49 and 51 percent respectively. The average age is 44 years. Education is measured as belonging to one of eight categories, from primary school and increasing to advanced degrees, including Ph.D. ${ }^{5}$ Individuals were asked to report their (monthly, pre-tax) income bracket. The majority of the individuals in our sample are employed (57\%). The second largest group are retired (16\%) followed by unemployed (8\%), students (12\%) and self-employed (6\%). ${ }^{6}$ The sample is reasonably representative of the Swedish population (see Almenberg and Widmark 2011 for further discussion).

The data indicate that women are less likely to participate in the stock market. Women are also more educated, have lower incomes, score lower on basic financial literacy as well as advanced financial literacy, and are less risk taking than men (more prone to indicate that they take less risk than the median amount in the sample). Table 1 below presents means and

\footnotetext{
${ }^{4}$ We have also tested using a binary variable that is 0 if the individual is below the median in risk taking and 1 otherwise. Overall, the results are very similar if we instead include the binary risk taking variable.

${ }^{5}$ Due to relatively small number of respondents holding an M.Phil or Ph.D., these are grouped together with holders of master's degrees as one category in the analysis.

${ }^{6}$ The category "employed" includes individuals in part-time employment. The category "students" includes those with part time employment but who reported that studying was their main occupation. The category "unemployed" includes those on long term sick leave.
} 
standard deviations for the variables of key relevance for this paper. The right-most column of Table 1 contains the t-statistics testing the null hypothesis of equal means for men and women.

Table 1. Summary statistics.

\begin{tabular}{|c|c|c|c|}
\hline Gender & Mean (S.D.) & $\mathbf{N}$ & t-test of means \\
\hline \multicolumn{4}{|c|}{ Stock market participation ( 1 or 0 ) } \\
\hline Female & $0.49(0.50)$ & 640 & \multirow{2}{*}{3.9587} \\
\hline Male & $0.59(0.49)$ & 659 & \\
\hline \multicolumn{4}{|l|}{ Age (yrs) } \\
\hline Female & 44.8 (17.6) & 630 & \multirow{2}{*}{0.4397} \\
\hline Male & $45.2(17.8)$ & 652 & \\
\hline \multicolumn{4}{|c|}{ Education (8 categories) } \\
\hline Female & $3.02(1.24)$ & 636 & \multirow{2}{*}{-2.5397} \\
\hline Male & $2.84(1.27)$ & 657 & \\
\hline \multicolumn{4}{|c|}{ Income (8 categories) } \\
\hline Female & $2.62(1.70)$ & 577 & \multirow{2}{*}{9.1697} \\
\hline Male & $3.63(2.01)$ & 570 & \\
\hline \multicolumn{4}{|c|}{ Basic financial literacy (0-6) } \\
\hline Female & $4.23(1.38)$ & 640 & \multirow{2}{*}{6.6812} \\
\hline Male & $4.73(1.28)$ & 659 & \\
\hline \multicolumn{4}{|c|}{ Advanced financial literacy (0-6) } \\
\hline Female & 3.49 (1.46) & 640 & \multirow{2}{*}{8.9118} \\
\hline Male & $4.17(1.30)$ & 659 & \\
\hline \multicolumn{4}{|c|}{ Risk taking (1-10) } \\
\hline Female & $3.98(2.39)$ & 640 & \multirow{2}{*}{7.5634} \\
\hline Male & $4.99(2.41)$ & 659 & \\
\hline
\end{tabular}

As Table 1 indicates, women score lower on both types of financial literacy than men. This gender gap remains significant also when we control for the demographic variables in a regression analysis (see Appendix Table A1).

\subsection{Regression analysis}

We explore how basic financial literacy affects the observed gender gap in stock market participation at the extensive margin, using a probit regression framework with robust standard errors. Table 2 reports the results from six probit regressions with stock market participation as the dependent variable. ${ }^{7}$ The coefficients are marginal effects. ${ }^{8}$

\footnotetext{
${ }^{7}$ The results are very similar when we use an OLS regression framework or a logistic regression framework.
} 
Women participate overall significantly less than men do $(\mathrm{p}<0.001)$. Controlling for age, education and income reduces the coefficient on gender by more than half and the coefficient becomes only marginally statistically significant ( $\mathrm{p}=0.099$ ). In column (3) we also control for basic financial literacy, which is positively and significantly related to stock market participation $(\mathrm{p}<0.001)$. This supports the findings of Christelis et al. (2010), who use a closely related measure. ${ }^{9}$ Including this control, the female coefficient is reduced by about two thirds compared to column 1 and seizes to be even marginally significantly different from zero $(\mathrm{p}=0.289)$. The basic financial literacy variable remains positive and significant $(p=0.037)$ when we include a control for advanced financial literacy, which is positive and highly significant $(\mathrm{p}<0.001)$, and the gender coefficient almost completely disappears (see column 4).

Women are typically more risk averse than men on average (see, e.g., Eckel and Grossman 2008, Croson and Gneezy 2009, or Bertrand 2011 for reviews). Meanwhile, stock market participation is related to risk aversion (Haliassos and Bertaut 1995, Barsky et al. 1997, Dohmen et al. 2011, van Rooij et al. 2011, Halko et al. forthcoming), although risk preferences alone are insufficient to explain non-participation: standard economic theory predicts that risk averse individuals will hold less stocks, but not opt out completely. ${ }^{10}$ It is thus important to also control for risk preferences or risk attitudes when exploring the gender gap in stock market participation. Including the control for risk attitudes from the selfreported measure do not alter the results substantially (as in van Rooij et al. 2011 who investigate advanced financial literacy). The financial literacy variables are qualitatively similar to before, and the coefficient on being female is no longer negative: the estimated coefficient even becomes positive but it is not statistically significant from zero (see column 5). However, given that advanced financial literacy is likely to be endogenous, we also test excluding this variable while including risk attitudes. The female coefficient is almost gone whereas both basic financial literacy $(p=0.001)$ and risk attitudes $(p<0.001)$ correlate positively with stock market participation (see column 6).

\footnotetext{
${ }^{8}$ The total sample includes 1299 individuals. When adding the control variables reported in column (2) in Table 2, the sample is reduced to 1132 individuals. In order to compare the size of the coefficients for being female, we restrict the sample also in column (1) to only contain these 1132 individuals. The size and significance of the gender gap in the unrestricted sample is very similar to that of the restricted sample (coeff $=-0.109, p<0.001$ ).

${ }^{9}$ Their measure is a subset of four of the six questions that we use.

${ }^{10}$ In a very large sample of bank clients in Finland, Halko et al. (forthcoming) find that the gender gap in stock market participation disappears when controls for risk attitude, self-assessed financial knowledge (not financial literacy) and education are included, and actually shifts sign and is significant when income and wealth controls are included.
} 
Table 2. Gender and stock market participation, probit regressions.

\begin{tabular}{|c|c|c|c|c|c|c|}
\hline & (1) & (2) & (3) & (4) & (5) & (6) \\
\hline \multirow[t]{2}{*}{ Female } & -0.119 & -0.055 & -0.036 & -0.000 & 0.018 & -0.013 \\
\hline & $(4.00) * * *$ & $(1.65)^{*}$ & (1.06) & $(0.01)$ & $(0.50)$ & (0.39) \\
\hline \multirow[t]{2}{*}{ Age } & & 0.009 & 0.007 & 0.003 & 0.004 & 0.008 \\
\hline & & (1.30) & (1.03) & $(0.37)$ & $(0.51)$ & (1.13) \\
\hline \multirow[t]{2}{*}{ Age $^{2}$} & & -0.000 & -0.000 & -0.000 & -0.000 & -0.000 \\
\hline & & (1.02) & $(0.71)$ & $(0.16)$ & $(0.17)$ & $(0.68)$ \\
\hline \multirow[t]{2}{*}{ Educ 2} & & 0.186 & 0.165 & 0.148 & 0.148 & 0.165 \\
\hline & & $(3.16)^{* * *}$ & $(2.78)^{* * *}$ & $(2.43)^{* *}$ & $(2.43)^{* *}$ & $(2.77)^{* * *}$ \\
\hline \multirow[t]{2}{*}{ Educ 3} & & 0.160 & 0.141 & 0.123 & 0.126 & 0.143 \\
\hline & & $(2.58)^{* *}$ & $(2.21)^{* *}$ & $(1.90)^{*}$ & $(1.94)^{*}$ & $(2.24)^{* *}$ \\
\hline \multirow[t]{2}{*}{ Educ 4} & & 0.242 & 0.202 & 0.165 & 0.166 & 0.200 \\
\hline & & $(4.09) * * *$ & $(3.29)^{* * *}$ & $(2.60) * * *$ & $(2.60) * * *$ & $(3.24) * * *$ \\
\hline \multirow[t]{2}{*}{ Educ 5} & & 0.394 & 0.366 & 0.330 & 0.325 & 0.360 \\
\hline & & $(5.68) * * *$ & $(4.99)^{* * *}$ & $(4.24) * * *$ & $(4.17) * * *$ & $(4.87)^{* * *}$ \\
\hline \multirow[t]{2}{*}{ Educ 6} & & 0.429 & 0.415 & 0.413 & 0.412 & 0.414 \\
\hline & & $(3.66)^{* * *}$ & $(3.33)^{* * *}$ & $(3.48)^{* * *}$ & $(3.49) * * *$ & $(3.35)^{* * *}$ \\
\hline \multirow[t]{2}{*}{ Inc 2} & & 0.120 & 0.113 & 0.120 & 0.115 & 0.107 \\
\hline & & $(2.50)^{* *}$ & $(2.34)^{* *}$ & $(2.48)^{* *}$ & $(2.33)^{* *}$ & $(2.19)^{* *}$ \\
\hline \multirow[t]{2}{*}{ Inc 3} & & 0.124 & 0.118 & 0.114 & 0.108 & 0.110 \\
\hline & & $(2.52)^{* *}$ & $(2.39)^{* *}$ & $(2.28)^{* *}$ & $(2.13)^{* *}$ & $(2.19)^{* *}$ \\
\hline \multirow[t]{2}{*}{ Inc 4} & & 0.221 & 0.208 & 0.199 & 0.183 & 0.189 \\
\hline & & $(4.20)^{* * *}$ & $(3.90)^{* * *}$ & $(3.68)^{* * *}$ & $(3.33)^{* * *}$ & $(3.47)^{* * *}$ \\
\hline \multirow[t]{2}{*}{ Inc 5} & & 0.267 & 0.257 & 0.239 & 0.222 & 0.238 \\
\hline & & $(4.58) * * *$ & $(4.33) * * *$ & $(3.89) * * *$ & $(3.57) * * *$ & $(3.94) * * *$ \\
\hline \multirow[t]{2}{*}{ Inc 6} & & 0.320 & 0.310 & 0.296 & 0.268 & 0.278 \\
\hline & & $(4.21)^{* * *}$ & $(3.98) * * *$ & $(3.75) * * *$ & $(3.28) * * *$ & $(3.43) * * *$ \\
\hline \multirow[t]{2}{*}{ Inc 7} & & 0.394 & 0.379 & 0.367 & 0.350 & 0.360 \\
\hline & & $(6.13) * * *$ & $(5.74)^{* * *}$ & $(5.49) * * *$ & $(5.10) * * *$ & $(5.29) * * *$ \\
\hline \multirow[t]{2}{*}{ Basic FL } & & & 0.045 & 0.028 & 0.028 & 0.044 \\
\hline & & & $(3.52)^{* * *}$ & $(2.08)^{* *}$ & $(2.08)^{* *}$ & $(3.42) * * *$ \\
\hline Advanced FL & & & & 0.072 & 0.068 & \\
\hline Risk taking & & & & $(5.51)^{* * *}$ & $\begin{array}{c}(5.19)^{* * *} \\
0.024\end{array}$ & 0.028 \\
\hline Risk taking & & & & & $\begin{array}{c}0.024 \\
(3.42)^{* * *}\end{array}$ & $(3.90) * * *$ \\
\hline Observations & 1132 & 1132 & 1132 & 1132 & 1132 & 1132 \\
\hline
\end{tabular}

\subsection{Risk attitudes}

We also explore whether financial literacy can explain the gender gap in risk taking, given that women are typically less risk taking than men and that financial literacy turned out to be an successful in explaining the gender gap in stock market participation. As indicated in Table 1 above, women self-report to be significantly less risk taking than men $(\mathrm{p}<0.001)$. Table 3 summarizes the results from three nested OLS regressions with risk taking as the dependent variable. Controlling for age, education and income, the coefficient of being female on risk taking drops somewhat but is still negative and significant $(\mathrm{p}<0.001)$. When we also control 
for basic and advanced financial literacy, we find that advanced financial literacy is positively correlated with risk taking $(\mathrm{p}=0.001)$ whereas basic financial literacy is not correlated $(p=0.723) .{ }^{11}$ The female coefficient remains significantly negatively correlated with risk taking ( $\mathrm{p}<0.001$ ), although the inclusion of control variables (column 3 compared to column 1) decreases its size by more than one third.

Table 3. Gender and risk taking, OLS regressions.

\begin{tabular}{|c|c|c|c|}
\hline & $(1)$ & (2) & (3) \\
\hline Female & $\begin{array}{c}-1.094 \\
(7.65)^{* * *}\end{array}$ & $\begin{array}{c}-0.800 \\
(5.53) * * *\end{array}$ & $\begin{array}{c}-0.682 \\
(4.66)^{* * *}\end{array}$ \\
\hline Age & & -0.037 & -0.051 \\
\hline & & $(1.23)$ & $(1.68)^{*}$ \\
\hline Age $^{2}$ & & 0.000 & 0.000 \\
\hline & & $(0.12)$ & $(0.54)$ \\
\hline Educ 2 & & $\begin{array}{l}0.158 \\
(0.58)\end{array}$ & $\begin{array}{l}0.055 \\
(0.20)\end{array}$ \\
\hline Educ 3 & & $\begin{array}{l}0.031 \\
(0.10)\end{array}$ & $\begin{array}{l}-0.075 \\
(0.24)\end{array}$ \\
\hline Educ 4 & & $\begin{array}{l}0.252 \\
(0.91)\end{array}$ & $\begin{array}{l}0.057 \\
(0.20)\end{array}$ \\
\hline Educ 5 & & $\begin{array}{c}0.737 \\
(2.17)^{* *}\end{array}$ & $\begin{array}{l}0.466 \\
(1.35)\end{array}$ \\
\hline Educ 6 & & $\begin{array}{l}0.339 \\
(0.83)\end{array}$ & $\begin{array}{l}0.120 \\
(0.30)\end{array}$ \\
\hline Inc 2 & & $\begin{array}{l}0.339 \\
(1.44)\end{array}$ & $\begin{array}{l}0.342 \\
(1.46)\end{array}$ \\
\hline Inc 3 & & $\begin{array}{c}0.444 \\
(1.82)^{*}\end{array}$ & $\begin{array}{c}0.413 \\
(1.69)^{*}\end{array}$ \\
\hline Inc 4 & & $\begin{array}{c}0.997 \\
(4.01)^{* * *}\end{array}$ & $\begin{array}{c}0.926 \\
(3.71)^{* * *}\end{array}$ \\
\hline Inc 5 & & $\begin{array}{c}1.128 \\
(4.11)^{* * *}\end{array}$ & $\begin{array}{c}1.035 \\
(3.73)^{* * *}\end{array}$ \\
\hline Inc 6 & & $\begin{array}{c}1.876 \\
(5.70)^{* * *}\end{array}$ & $\begin{array}{c}1.774 \\
(5.34)^{* * *}\end{array}$ \\
\hline Inc 7 & & $\begin{array}{c}1.663 \\
(5.39)^{* * *}\end{array}$ & $\begin{array}{c}1.539 \\
(4.97)^{* * *}\end{array}$ \\
\hline Basic FL & & & $\begin{array}{l}0.021 \\
(0.35)\end{array}$ \\
\hline Advanced FL & & & $\begin{array}{c}0.182 \\
(3.25)^{* * *}\end{array}$ \\
\hline Constant & $\begin{array}{c}5.092 \\
(50.26)^{* * *}\end{array}$ & $\begin{array}{c}5.664 \\
(9.35)^{* * *}\end{array}$ & $\begin{array}{c}5.300 \\
(8.36)^{* * *}\end{array}$ \\
\hline Observations & 1132 & 1132 & 1132 \\
\hline R-squared & 0.05 & 0.16 & 0.17 \\
\hline
\end{tabular}

\footnotetext{
${ }^{11}$ When performing a regression including the demographic variables and basic financial literacy, the latter is not significant $(\mathrm{p}=0.233)$.
} 
Dohmen et al. (2010) have previously found cognitive ability to be positively related to risk taking measured by this type of question. There are also other studies relating cognitive ability to risk taking (Frederick 2005, Benjamin et al. 2006). The fact that we do not find an association between numeracy and risk taking here suggests this relationship might be mediated by other variables, which we control for in our analysis. Simply correlating risk taking with numeracy, we find a significant correlation $(\mathrm{r}=0.18, \mathrm{p}<0.001)$, whereas this relationship is no longer present once we control for a number of other variables. ${ }^{12}$ To what extent others' findings are driven by numeracy-like variables being correlated with other correlates of risk taking remains to be explored.

\section{Discussion}

This paper contributes to the growing literature linking financial literacy to economic decision making. Previous work on stock market participation has tended to focus on advanced financial literacy, which is likely to be partly endogenous with regard to stock market experience. By contrast, basic financial literacy is likely to be exogenous to stock market participation for most individuals. In a random sample, approximately representative of the Swedish population, we find that controlling for basic financial literacy reduces the gender gap in stock market participation. The effect is robust to including a separate control for advanced financial literacy.

When it comes to risk attitudes, the gender gap remains significant when controlling for financial literacy. Previous studies on financial literacy have not focused on explaining the gender gap in e.g. risk attitudes, with two exceptions. Dwyer et al. (2002) use data from a national survey of about 2000 mutual fund investors and find that women are less risk taking than men in their mutual fund investment decisions. The survey also contains questions on investor knowledge of financial markets and investments, basically measuring advanced financial literacy. ${ }^{13}$ Controlling for investor knowledge, the impact of gender on risk taking is significantly weakened. Halko et al. (forthcoming) find slightly different results in a sample of bank clients. Even though they do not look at financial literacy per se, they include questions on self-assessed investment knowledge and find that the gender gap in risk taking as

\footnotetext{
${ }^{12}$ The correlation is similar when we restrict the sample to only the 1132 individuals for whom we have all data.

${ }^{13}$ Investor-specific financial investment knowledge is measured through summing responses to a 12-item scale that had potential scores ranging from 0 to 12 , where six of the scale items required responses that could be compared to a known answer. Dwyer et al. (2002) examined the types of mutual funds that respondents had purchased for their largest single investment, their most recent investment, and their riskiest investment, where the latter is a composite variable created by selecting the riskiest mutual fund type reported across all investment channels.
} 
measured from both subjective risk attitudes and the proportion of total wealth held in stocks conditional on holding some stock remains significant even when investment knowledge is controlled for. ${ }^{14}$ The authors find that the gender gap in stock market participation, however, disappears once controls for investment knowledge, risk attitudes and education are included, and actually flips in direction and is significant once income and wealth variables are included in the analysis. A limitation of these frameworks is that investor sophistication or knowledge is highly likely to be endogenous with regard to stock market experience, compared to basic financial literacy measures such as numeracy. Nonetheless, these results also suggest that the gender gap in important domains of economic decision making can be reduced with appropriate controls for financial literacy or related variables. Our results contribute to this line of research by using standard measures of financial literacy, by distinguishing between basic and advanced financial literacy, and by using a random sample that is broadly representative of the entire adult population.

In many countries, policy reforms and financial development are increasingly putting individuals in charge of making key economic decisions, for example when it comes to saving for retirement. There is no a priori reason to expect men and women to respond the same way to these challenges. It is well established that men and women differ with regard to economic outcomes and also with regard to financial literacy. Improving our understanding of links between financial literacy and economic decision making is thus also important for understanding the observed gender differences in economic outcomes.

\section{References}

Agarwal, S., Driscoll, J., Gabaix, X., Laibson, D., 2009. The age of reason: Financial decisions over the life-cycle with implications for regulation. Brookings Papers on Economic Activity, 51-117.

Almenberg, J., Säve-Söderbergh, J., 2011. Financial literacy and planning for retirement among Swedish adults. Mimeo.

Almenberg, J., Widmark, O., 2011. Numeracy, financial literacy and asset market participation. Journal of Pension Economics and Finance 10, 585-598.

Banks, J., Oldfield, Z., 2007. Understanding pensions: Cognitive function, numerical ability and retirement saving. Fiscal Studies 28, 143-170.

\footnotetext{
${ }^{14}$ Investment knowledge in Halko et al. (2011) is self-assessed on a three-point scale: beginner, intermediate, and advanced.
} 
Barsky, R.B., Juster, F.T., Kimball, M.S., Shapiro, M.D., 1997. Preference parameters and behavioral heterogeneity: An experimental approach in the health and retirement study. Quarterly Journal of Economics 112, 537-579.

Benjamin, D.J., Brown, S.A., Shapiro, J.M., 2006. Who is "behavioral”? Cognitive ability and anomalous preferences. Mimeo.

Bertrand, M., 2011. New perspectives on gender. In: Ashenfelter, O., Card, D., (Eds.), Handbook of Labor Economics, Vol. 4b, forthcoming.

Campbell, J., 2006. Household finance.” Journal of Finance 61, 1553-1604.

Christelis, D., Jappelli, T., Padula, M. 2007. Cognitive abilities and portfolio choice. European Economic Review 54, 18-38.

Cocco, J.F., Gomes, F.J., Maenhout, P.J., 2005. Consumption and portfolio choice over the life cycle. Review of Financial Studies 18, 491-533.

Croson, R., Gneezy, U., 2009. Gender differences in preferences. Journal of Economic Literature 47, 1-27.

Dohmen, T., Falk, A., Huffman, D., Sunde, U., 2010. Are risk aversion and impatience related to cognitive ability? American Economic Review 100, 1238-1260.

Dohmen, T., Falk, A., Huffman, D., Sunde, U., Schupp, J., Wagner,G.G., 2011. Individual risk attitudes: Measurement, determinants and behavioral consequences. Journal of the European Economic Association 9, 522-550.

Dwyer, P.D., Gilkeson, J.H., List, J.A., 2002. Gender differences in revealed risk taking: Evidence from mutual fund investors. Economics Letters 76, 151-158.

Eckel, C., Grossman, P., 2008. Men, women and risk aversion: Experimental evidence. In: Plott, C., Smith, V. (Eds.), Handbook on Experimental Economics Results, Vol. 1. Elsevier, New York.

Frederick, S., 2005. Cognitive reflection and decision making. Journal of Economic Perspectives 19, 25-42.

Grinblatt, M., Keloharju, M., Linnainmaa, J., 2011. IQ and stock market participation. Journal of Finance, forthcoming.

Guiso, L., Jappelli, T. 2005. Awareness and stock market participation. Review of Finance 9, 537-567.

Guiso, L., Sapienza, P., Zingales, L., 2008. Trusting the stock market. Journal of Finance 63, 2557-2600.

Haliassos, M., Bertaut, C.C., 1995. Why do so few hold stocks? Economic Journal 105, $1110-$ 1129.

Halko, M.-L., Kaustia, M., Alanko, E., 2011. The gender effect in risky asset holdings. Journal of Economic Behavior and Organization, forthcoming.

Hong, H., Kubik, J.D., Stein, J.C., 2004. Social interaction and stock market participation. Journal of Finance 59, 137-163.

Hung, A. A., Parker, A. M., Yoong, J. K., 2009. Defining and measuring financial literacy. RAND working paper.

Kezdi, G., Willis, R.J., 2006. Who becomes a stockholder? Expectations, subjective uncertainty, and asset allocation.” Mimeo. 
Lusardi, A., Mitchell, O., 2006. Financial literacy and planning: Implication for retirement wellbeing. Mimeo.

Lusardi, A., Mitchell, O., 2007. Baby boomer retirement security: The role of planning, financial literacy, and housing wealth. Journal of Monetary Economics 54, 205-224.

Lusardi, A., Mitchell, O., 2008. Planning and financial literacy: How do women fare? American Economic Review 98, 413-417.

Lusardi, A., Tufano, P., 2009. Debt literacy, financial experiences, and overindebtedness. Mimeo.

McArdle, J.J., Smith, P., Willis, R., 2009. Cognition and economic outcomes in the health and retirement survey. Mimeo.

van Rooij, M.C.J., Lusardi, A., Alessie, R.J.M., 2011. Financial literacy and stock market participation. Journal of Financial Economics, forthcoming.

Steel, N., Huppert, F., Williams, B., Melzer, D., 2003. Physical and cognitive function. In: Marmott, M., Banks, J., Blundell, R., Lessof, C., Nazroo, J., (Eds.), Health, Wealth and Lifestyles of the Older Population in England: The 2002 English Longitudinal Study of Ageing. Institute for Fiscal Studies, London.

Vestman, R., 2010. Limited stock market participation among renters: Explanations and welfare consequences. Mimeo.

Vissing-Jørgensen, A., 2003. Perspectives on behavioral finance: Does "irrationality" disappear with wealth? Evidence from expectations and actions. NBER Macroeconomics Annual. 


\section{Appendix}

Numeracy questions. (wording in Swedish/wording translated into English/ELSA wording)

Q1 Du köper en bok för 85 kr och betalar med 100 kr. Hur mycket växel borde du få? /You buy a book for SEK 85 and pay with SEK 100. How much change should you get?/ If you buy a drink for 85 pence and pay with a one pound coin, how much change should you get?

Q2 En butik har rea och erbjuder då alla sina varor till halva priset. En stol kostar 3000 kr innan rean. Hur mycket kostar den under rean? /A shop has a sale and offers all items at half price. A chair costs SEK 3,000 before the sale. How much does it cost in the sale?/ In a sale, a shop is selling all items at half price. Before the sale, a sofa costs $£ 300$. How much will it cost in the sale?

Q3 Om sannolikheten att få en sjukdom är 10\%, hur många av 1000 personer kan förväntas få sjukdomen?/ If the probability of getting a disease is 10 per cent, how many people out of 1,000 would be expected to get the disease?/ If the chance of getting the disease is 10 per cent, how many people out of 1,000 would be expected to get the disease?

Q4 En bilhandlare erbjuder en begagnad bil för 60000 kr. Det är två tredjedelar av vad den kostade som ny. Hur mycket kostade bilen som ny?/ A car dealer offers a second hand car for SEK 60,000. This is two-thirds of what it cost new. How much did the car cost new?/ A second hand car dealer is selling a car for $£ 6,000$. This is two-thirds of what it cost new. How much did the car cost new?

Q5 Fem personer vinner ett lottery och ska dela på vinsten. Om vinsten de ska dela på är 2 miljoner, hur mycket får var och en?/ Five people win a lottery and share the prize. If the prize they are sharing is 2 million, how much does each of them get?/ If 5 people all have the winning numbers in the lottery and the prize is $£ 2$ million, how much will each of them get?

Q6 Anta att du har 200 kr på ett sparkonto. Räntan är 10\% om året och sätts in på samma konto. Hur mycket har du på kontot efter två år?/ Suppose you have SEK 200 in a savings account. The interest is 10 per cent per year and is paid into the same account. How much will you have in the account after two years?/ Let's say you have $£ 200$ in a savings account. The account earns ten per cent interest per year. How much will you have in the account at the end of two years? 
Financial literacy questions (wording in Swedish/wording translated into English/wording in previous surveys e.g. HRS)

Q1 Anta att räntan på ditt sparkonto är 1\% och inflationen är 2\%. Om du låter dina pengar stå på kontot i ett år, kommer du kunna köpa mer, lika mycket, eller mindre för pengarna vid årets slut?/ Suppose the interest on your bank account is 1 per cent and inflation is 2 per cent. If you keep your money in the account for a year, will you be able to buy more, as much, or less at the end of the year?/ Imagine that the interest rate on your savings account was 1 per cent per year and inflation 2 per cent per year. After 1 year, would you be able to buy more than, exactly the same as, or less than today with the money in this account?

Q2 .’Att köpa aktier i ett enstaka företag är vanligtvis säkrare än att köpa andelar i en aktiefond.” Sant eller falskt?/ Buying stock in a single company is usually safer than buying shares in a mutual fund. True or false?/ Do you think the following statement is true or false? "Buying a single company stock usually provides a safer return than a stock mutual fund.” Q3 Obligationer är värdepapper som löper med fast ränta under viss tid. Om räntan går ner, vad händer med obligationspriserna?/ Bonds are securities that pay a fixed interest during a specified time period. If interest rates go down, what happens to bond prices?/ If the interest rate falls, what should happen to bond prices?

Q4 Vilket har historiskt sett gett högst avkastning på lång sikt, aktier eller obligationer?/ Which has had the higher historical long-run return, stocks or bonds?/ Considering a long time period (for example 10 or 20 years), which asset normally gives the highest return? [savings accounts/ bonds/stocks]

Q5 “Aktier brukar gå upp och ner i värde mer än vad obligationer gör.”Sant eller falskt?/ Stocks tend to fluctuate more in value than bonds. True or false?/ Normally, which asset displays the highest fluctuations over time: savings accounts, bonds or stocks?

Q6 ’En investering som ger högre avkastning än genomsnittet har sannolikt högre risk än genomsnittet.” Sant eller falskt?/ An investment that pays an above average return is likely to have above average risk. True or false 
Appendix Table A1. Gender, basic and advanced financial literacy, OLS regressions.

\begin{tabular}{|c|c|c|c|c|}
\hline & \multicolumn{2}{|c|}{ Basic FL } & \multicolumn{2}{|c|}{ Advanced FL } \\
\hline & (1) & (2) & (3) & (4) \\
\hline \multirow[t]{2}{*}{ Female } & -0.493 & -0.423 & -0.688 & -0.601 \\
\hline & $(6.20)^{* * *}$ & $(5.29)^{* * *}$ & $(8.34)^{* * *}$ & $(7.41)^{* * *}$ \\
\hline \multirow[t]{2}{*}{ Age } & & 0.035 & & 0.072 \\
\hline & & $(1.98)^{* *}$ & & $(4.09)^{* * *}$ \\
\hline \multirow[t]{2}{*}{$\mathrm{Age}^{2}$} & & 0.000 & & -0.001 \\
\hline & & $(2.26)^{* *}$ & & $(3.70)^{* * *}$ \\
\hline \multirow[t]{2}{*}{ Educ 2} & & 0.516 & & 0.510 \\
\hline & & $(3.34)^{* * *}$ & & $(3.17)^{* * *}$ \\
\hline \multirow[t]{2}{*}{ Educ 3} & & 0.549 & & 0.516 \\
\hline & & $(3.30)^{* * *}$ & & $(3.03)^{* * *}$ \\
\hline \multirow[t]{2}{*}{ Educ 4} & & 1.049 & & 0.954 \\
\hline & & $(6.79)^{* * *}$ & & $(5.88)^{* * *}$ \\
\hline \multirow[t]{2}{*}{ Educ 5} & & 1.269 & & 1.340 \\
\hline & & $(7.39)^{* * *}$ & & $(7.29)^{* * *}$ \\
\hline Educ 6 & & $\begin{array}{c}1.064 \\
(386)^{* * * *}\end{array}$ & & 1.082 \\
\hline \multirow[t]{2}{*}{ Inc 2} & & 0.188 & & $\begin{array}{l}(3.04) \\
-0.035\end{array}$ \\
\hline & & $(1.43)$ & & $(0.25)$ \\
\hline \multirow[t]{2}{*}{ Inc 3} & & 0.186 & & 0.147 \\
\hline & & (1.38) & & $(1.08)$ \\
\hline \multirow[t]{2}{*}{ Inc 4} & & 0.448 & & 0.335 \\
\hline & & $(3.34)^{* * *}$ & & $(2.37)^{* *}$ \\
\hline \multirow[t]{2}{*}{ Inc 5} & & 0.399 & & 0.470 \\
\hline & & $(2.38)^{* *}$ & & $(3.09)^{* * *}$ \\
\hline \multirow[t]{2}{*}{ Inc 6} & & 0.502 & & 0.500 \\
\hline & & $(2.70)^{* * *}$ & & $(2.61)^{* * *}$ \\
\hline \multirow[t]{2}{*}{ Inc 7} & & 0.711 & & 0.600 \\
\hline & & $(4.71)^{* * *}$ & & $(3.75)^{* * *}$ \\
\hline \multirow[t]{2}{*}{ Constant } & 4.732 & 3.169 & 4.176 & 1.637 \\
\hline & $(87.23)^{* * *}$ & $(8.87)^{* * *}$ & $(75.64)^{* * *}$ & $(4.44) * * *$ \\
\hline Observations & 1132 & 1132 & 1132 & 1132 \\
\hline R-squared & 0.03 & 0.19 & 0.06 & 0.22 \\
\hline
\end{tabular}

